\title{
PRODUKSI ENZIM KITINASE DARI Aspergillus niger MENGGUNAKAN LIMBAH CANGKANG RAJUNGAN SEBAGAI INDUSER
}

\author{
Purkan Purkan $^{1 *}$, Afaf Baktir ${ }^{1}$, Arju Rohmah Sayyidah ${ }^{1}$ \\ ${ }^{1}$ Departemen Kimia Fakultas Sains dan Teknologi \\ Universitas Airlangga \\ *email: purkan@fst.unair.ac.id
}

\begin{abstract}
Abstrak
Kitinase merupakan enzim hidrolitik yang dapat menghidrolisis kitin pada ikatan $\beta-1,4-$ glikosidiknya dengan menghasilkan derivat-derivat kitin seperti oligomer kitin yang mempunyai banyak manfaat. Penelitian ini bertujuan untuk melakukan pengembangan produksi enzim kitinase dari sumber lokal yang melimpah di alamserta murah dengan melakukan optimasi substrat dalam hal ini digunakan substrat tetes tebu (molase) dan limbah cangkang rajungan untuk produksi enzim kitinase dari Aspergillus niger. Sebelumnya, dilakukan kultivasi isolat kapang Aspergillus niger dengan membuat kurva pertumbuhan menggunakan metode masa sel kering dimana dari hasil penelitian inokulasi optimal adalah 22 jam. Pada proses produksi, diperoleh waktu fermentasi optimal adalah 52 jam dengan menentukan uji aktivitasnya menggunakan metode turbidimetri. Hasil optimasi substrat menunjukkan bahwa enzim kitinase yang maksimal diperoleh pada penambahan molase $0,5 \%(\mathrm{~b} / \mathrm{v})$ dengan unit aktivitas enzim $0,14726(\mathrm{U} / \mathrm{mL})$ dan cangkang rajungan $2 \%$ (b/v) dengan unit aktivitas enzim yang dihasilkan 0,12826 (U/mL). Kitinase dari Aspergillus niger ini mempunyai $\mathrm{pH}$ optimal 6 dan suhu optimal $40{ }^{\circ} \mathrm{C}$.
\end{abstract}

Kata kunci: Aspergillus niger, kitinase, cangkang rajungan, molase

\begin{abstract}
Chitinase is a hydrolytic enzyme that hydrolyzes chitin on $\beta$-1,4-glycosidic bond and thereby producing chitin derivatives such as chitin oligomers that have multiple benefits. The purpose of this research was to develop the production of chitinase enzyme from cheap and are abundant local nature sources, by optimizations substrate in this case the substrate used molasses and crab shell waste for the production of chitinase enzyme from Aspergillus niger. Previously, isolates of Aspergillus niger cultivated by creating a growth curve using dry cell mass method which from the results of research inoculation optimal are 22 hours. In the production process, obtained the optimum fermentation time is 52 hours to determine the activity test using turbidimetry method. Result of substrate optimizations indicate that chitinase enzyme maximum by addition of molasses obtained in $0.5 \%(\mathrm{w} / \mathrm{v})$ with enzyme activity units $0.14726(\mathrm{U} / \mathrm{mL})$ and crab shells $2 \%(\mathrm{w} / \mathrm{v})$ with enzyme activity units 0.12826 $(\mathrm{U} / \mathrm{mL})$. Chitinase from Aspergillus niger has a $\mathrm{pH}$ optimum 6 and temperature optimum $40{ }^{\circ} \mathrm{C}$.
\end{abstract}

Keywords: Aspergillus niger, chitinase, crab shells, molasses

\section{Pendahuluan}

Salah satu penerapan bioteknologi yang terus berkembang adalah pemanfaatan enzim dari mikroorganisme untuk biodegradasi. Dalam biodegradasi, enzim dari mikroorganisme berperan untuk 
memecah molekul-molekul besar atau polimer yang ada di alam menjadi produk yang dapat dimanfaatkan. Salah satu polimer alam yang keberadaannya melimpah adalah kitin dimana secara umum enzim yang mendegradasi kitin adalah jenis enzim kitinase.

Kitinase merupakan enzim hidrolitik yang dapat menghidrolisis kitin pada ikatan $\quad \beta$-1,4-glikosidiknya dengan menghasilkan derivat-derivat kitin seperti oligomer kitin. Beberapa penelitian telah mencoba menghidrolisis kitin dengan enzim yang dihasilkan oleh Aspergillus $s p$, Bacillus sp, Clostridium sp, Serratia $s p$, Aeromonas sp, dan Trichoderma $s p$. (Maggadani, 2012). Aspergillus niger merupakan jenis kapang yang dapat mensekresikan enzim selulase, kitinase, $\alpha$ amilase, $\quad \alpha$-amilase, glukoamilase, katalase, pektinase, lipase, laktase, invertase, dan asam protease.

Kitinase mempunyai banyak manfaat antara lain sebagai antihama karena sifatnya yang dapat mematikan serangga (entomopatogenisitas), kitinase dari bakteri dilaporkan pula oleh Regev et al. (1996) bersinergi dengan endotoksin dari $B$. thuringiensis dalam menekan larva Spodoptera littoralis pada tebu (Toharisman, 2007). Hasil hidrolisis kitin oleh kitinase juga menghasilkan Nasetilglukosamin yang digunakan untuk pengawet, substrat untuk perbaikan jaringan dan reaksi antiinflamasi, meningkatkan kelembaban dan keelastisan kulit, penyembuhan luka (Chen et al., 2010), terapi pengobatan osteoarthritis (nyeri sendi) dan sebagai makanan suplemen (Sashiwa et al., 2002). Nasetilglukosamin juga dapat dikonversi menjadi hexa-N-kitobiosa yaitu suatu oligosakarida yang memiliki aktivitas antitumor (Patil et al., 2000).

Banyaknya manfaat enzim kitinase dan senyawa turunan kitin mengakibatkan meningkatnya kebutuhan enzim kitinase sehingga perlu dilakukan pengembangan produksi enzim kitinase dari sumber lokal yang melimpah di alam serta harganya yang relatif murah. Salah satunya adalah penggunaan limbah yang mengandung kitin. Kitin merupakan komponen penyusun peptodoglikan dinding sel mikroba yang banyak ditemukan pada eksoskeleton serangga, krustasea, dan dinding sel jamur (Chen et al., 2010). Di Indonesia udang dan kepiting merupakan komoditas yang memainkan peranan penting sebagai sumber kitin karena hasil pengolahannya banyak menghasilkan limbah. Menurut Peniston (1982) pengolahan udang dan kepiting menghasilkan limbah $50-60 \%$ dari berat utuh dengan kandungan kitin 20-30\%. Substrat fermentasi yang melimpah dan mudah didapat lainnya adalah molase (tetes tebu) yang merupakan hasil samping pembuatan gula dan pemanfaatannya masih sedikit. Menurut Dellweg (1983) kandungan gula dalam molase pada $75 \%$ bahan kering sebesar $62 \%$ (Widyanti, 2010). Sehingga penelitian ini bertujuan untuk melakukan optimasi produksi dan karakterisasi enzim kitinase dari Aspergillus niger menggunakan substrat molase (tetes tebu) dan kitin dari cangkang rajungan yang melimpah di alam Indonesia ini.

\section{Metode Penelitian}

\section{Alat dan Bahan}

Bahan yang digunakan dalam penelitian ini antara lain: limbah cangkang rajungan, $\mathrm{HCl} 5 \%, \mathrm{NaOH} 5 \%$, PDA, kapas, kasa, aluminium foil, $\mathrm{MgSO}_{4} \cdot 7 \mathrm{H}_{2} \mathrm{O}$, $\mathrm{KH}_{2} \mathrm{PO}_{4}, \mathrm{CaCl}_{2} \cdot 2 \mathrm{H}_{2} \mathrm{O}$, yeast ekstrak, glukosa, molase, $\mathrm{Na}_{2} \mathrm{HPO}_{4} \cdot 7 \mathrm{H}_{2} \mathrm{O}$, $\mathrm{NaH}_{2} \mathrm{PO}_{4}$, asam sitrat, dan akuades. Sedangkan peralatan terdiri dari termometer, magnetik stirer, tabung falcon, tabung Eppendorf, jarum ose, pipet tetes, lemari pendingin Toshiba Glacio dan Sanyo, mikropipet, tube, dan orbital shaker TS-330A. Instrumen yang digunakan diantaranya timbangan analitik Mettler Toledo AL204, sentrifuge Beckman (tipe TJ-6), laminar air flow cabinet Kottermann 8580, pH meter Mettler Toledo, inkubator Memmert, Sanstat 
Water Bath type SYK-382-M dan Gerhardt, autoclave electric model No. $25 \mathrm{X}$, vortex meter VM-300, dan spektrofotometer UV-VIS Shimadzu UV1800.

\section{Prosedur Penelitian \\ Pembuatan media}

Media padat untuk peremajaan isolat Aspergillus niger digunakan media Potato Dextrose Agar (PDA). Untuk media pertumbuhan terdiri dari ( $\mathrm{g} / \mathrm{L}$ air): $\mathrm{MgSO}_{4} \cdot 7 \mathrm{H}_{2} \mathrm{O} \quad 1,0 ; \quad \mathrm{KH}_{2} \mathrm{PO}_{4} \quad 1,5$; $\mathrm{CaCl}_{2} \cdot 2 \mathrm{H}_{2} \mathrm{O} \quad 0,2 ;$ yeast ekstrak 0,2 , glukosa, molase, ditambahkan dengan akuades, sedangkan untuk media produksi seperti media pertumbuhan dengan ditambah induser cangkang rajungan.

\section{Kultivasi isolat penghasil enzim kitinase}

Isolat Aspergillus niger diremajakan dengan cara memindahkan satu ose koloni dari stok biakan kedalam media padat yang telah disiapkan kemudian diinkubasi pada suhu $30 \square$ C selama 3 hari.

Untuk membuat kurva pertumbuhan dilakukan dengan metode masa sel kering. Isolat Aspergillus niger yang telah diremajakan dalam media padat diambil dengan kawat ose kemudian dimasukkan kedalam media pertumbuhan. Selanjutnya dilakukan inkubasi pada suhu ruang dengan penggojokan pada $170 \mathrm{rpm}$. Sampling dilakukan tiap 4 jam kemudian disaring dan dicuci dengan aquadest selanjutnya dikeringkan dengan oven sampai diperoleh masa sel kering yang konstan.

\section{Produksi enzim kitinase}

Sebanyak $1 \mathrm{~mL}$ inokulum ditambahkan kedalam $100 \mathrm{~mL}$ media produksi, kemudian di inkubasi pada suhu $30{ }^{\circ} \mathrm{C}$ dengan penggojokan $170 \mathrm{rpm}$ selama 6 hari, setelah itu disentrifugasi pada 3500 rpm selama 20 menit dengan suhu $4{ }^{\circ} \mathrm{C}$. Supernatan yang terbentuk setelah disentrifugasi adalah ekstrak kasar enzim kitinase atau crude enzyme chitinase yang selanjutnya diuji aktivitasnya. Penentuan
Aktivitas Enzim dilakukan dengan cara, $400 \mu \mathrm{L}$ enzim kitinase ditambah dengan $1600 \mu \mathrm{L}$ substrat kitin (1\% koloidal kitin $\mathrm{b} / \mathrm{v}$ dalam $50 \mathrm{mM}$ buffer fosfat $\mathrm{pH} 7$ ). Campuran diinkubasi pada suhu $37{ }^{\circ} \mathrm{C}$ selama 30 menit, kemudian dilakukan pengukuran aktivitas kitinase dengan diukur absorbansinya menggunakan spektrofotometer pada $\lambda 660 \mathrm{~nm}$.

\section{Optimasi waktu fermentasi}

Sebanyak $1 \mathrm{~mL}$ inokulum ditambahkan kedalam $100 \mathrm{~mL}$ media produksi kemudian diinkubasi pada suhu $30{ }^{\circ} \mathrm{C}$ dengan penggojokan $170 \mathrm{rpm}$ selama 6 hari. Sampel di ambil tiap 4 jam. Sampel disentrifugasi untuk di ambil supernatannya yang selanjutnya di lakukan uji aktivitas.

Optimasi konsentrasi molase untuk produksi enzim kitinase

Sebanyak $1 \mathrm{~mL}$ inokulum ditambahkan kedalam $100 \mathrm{~mL}$ media produksi dengan variasi konsentrasi molase 0,$2 ; 0,4 ; 0,5$; 0,$6 ; 0,8$; dan $1(\% \mathrm{~b} / \mathrm{v})$ dengan konsentrasi limbah cangkang rajungan dibuat sama sebesar $1 \%$. Media produksi kemudian diinkubasi pada suhu $30{ }^{\circ} \mathrm{C}$ dengan penggojokan $170 \mathrm{rpm}$ selama waktu fermentasi optimal yang telah diperoleh, kemudian enzim yang diperoleh diuji aktivitasnya.

Optimasi konsentrasi cangkang rajungan untuk produksi enzim kitinase

Sebanyak $1 \mathrm{~mL}$ inokulum ditambahkan kedalam $100 \mathrm{~mL}$ media produksi dengan variasi konsentrasi limbah cangkang rajungan sebesar $0,5 \%, 1 \%, 1,5 \%, 2 \%$, 2,5\%, dan 3\%. Konsentrasi molase yang ditambahkan besarnya disesuaikan dengan hasil optimasi yang telah diperoleh sebelumnya kemudian di inkubasi pada suhu $30{ }^{\circ} \mathrm{C}$ dengan penggojokan $170 \mathrm{rpm}$ selama waktu fermentasi optimal yang telah diperoleh, setelah itu enzim yang diperoleh diuji aktivitasnya. 


\section{Karakterisasi $p H$ enzim kitinase}

Penentuan $\mathrm{pH}$ optimum dilakukan dengan memasukkan ekstrak kasar enzim kitinase sebanyak $400 \mu \mathrm{l}$, dan ditambah dengan $1600 \mu 1$ substrat kitin (1\% koloidal kitin b/v dalam $50 \mathrm{mM}$ buffer). Masing masing tabung diinkubasi 30 menit pada $\mathrm{pH}$ yang berbeda-beda, yaitu $3,4,5,6,7$ dan 8. Dalam hal ini untuk pH 3, 4, 5, 6, dan 7 digunakan buffer fosfat sitrat sedangkan untuk $\mathrm{pH} \mathrm{6,7}$ dan 8 digunakan buffer fosfat.

\section{Karakterisasi suhu enzim kitinase}

Penentuan suhu optimum dilakukan dengan memasukkan ekstrak kasar enzim kitinase sebanyak $400 \mu 1$, dan ditambah dengan $1600 \mu \mathrm{L}$ substrat kitin (1\% koloidal kitin b/v dalam $50 \mathrm{mM}$ buffer). Masing - masing tabung diinkubasi selama 30 menit pada suhu yang berbeda - beda, yaitu $20^{\circ} \mathrm{C}, 30^{\circ} \mathrm{C}, 40^{\circ} \mathrm{C}, 50^{\circ} \mathrm{C}$ dan $60^{\circ} \mathrm{C}$.

\section{Hasil dan Pembahasan}

Kultivasi Isolat Kapang Aspergillus niger

Aspergillus niger yang telah menjadi koleksi laboratorium Biokimia Universitas Airlangga diremajakan dengan menanam kembali pada media padat Potato Dextrose Agar (PDA). Pertumbuhan ini diamati dengan munculnya spora berwarna hitam menyerupai bubuk kopi yang mulai terlihat pada hari ketiga.

Isolat yang telah diremajakan digunakan untuk pembuatan starter untuk menghasilkan sel-sel yang lebih aktif yang biasa disebut dengan inokulum. Untuk membuat inokulum ini perlu mengetahui pertumbuhan optimal kapang sehingga dilakukan pembuatan kurva pertumbuhan. Pada penelitian ini digunakan perhitungan massa sel kering untuk pembuatan kurva pertumbuhan. Untuk menghitung massa sel kering dilakukan inokulasi Aspergillus niger pada media pertumbuhan selama 3 hari, disampling tiap 4 jam disaring lalu dioven untuk mendapatkan massa sel kering yang konstan. Grafik hubungan antara waktu dan masa sel kering ditampilkan pada Gambar 1.
Dari Gambar 1 dapat diketahui bahwa pada waktu inkubasi 0 sampai 4 jam merupakan fase adaptasi (lag) yang merupakan tahap penyesuaian terhadap lingkungan baru. Pada waktu inkubasi 4 sampai 12 jam merupakan fase initial log, fase dimana sel-sel mulai membelah. Selanjutnya mulai waktu inkubasi 12 sampai 24 jam kapang mengalami mengalami fase log, fase dimana mikroba membelah dengan cepat dan konstan mengikuti kurva logaritmik.

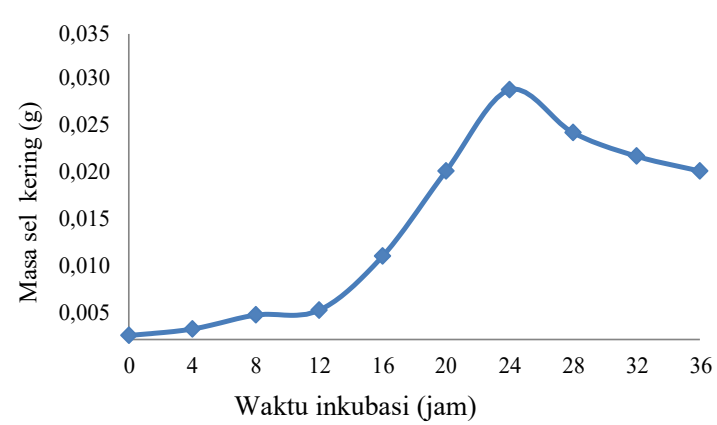

Gambar 1. Profil pertumbuhan Aspergillus niger

Pada waktu inkubasi 24 jam merupakan puncak namun sudah memasuki fase stasioner sampai waktu inkubasi 36 jam yang menunjukkan penurunan. Pada fase ini jumlah populasi sel tetap karena jumlah sel yang tumbuh sama dengan jumlah sel yang mati. Ukuran sel pada fase ini menjadi lebih kecil-kecil karena sel tetap membelah meskipun zat-zat nutrisi sudah habis. Karena kekurangan zat nutrisi, sel kemungkinan mempunyai komposisi berbeda dengan sel yang tumbuh pada fase logaritmik (Fardiaz, 1989).

Pada fase stationer ini juga dihasilkan metabolit sekunder seperti biosintesis koenzim, hormon, nukleotida, pigmen, toksin, enzim dan lain - lain. Berdasarkan kurva pertumbuhan tersebut didapatkan bahwa waktu inokulasi optimal Aspergillus niger adalah 22 jam.

\section{Produksi dan uji aktivitas enzim kitinase}

Enzim kitinase merupakan enzim ekstraseluler yang disekresikan kapang pada media produksinya. Enzim ini 
diperoleh dengan cara memisahkan sel kapang dengan media pertumbuhannya melalui sentrifugasi pada kecepatan 3500 rpm dan suhu $4^{\circ} \mathrm{C}$ sampai koloni yang terbentuk terpisah dari supernatan. Supernatan yang dihasilkan merupakan ekstrak kasar enzim kitinase.

Uji aktivitas kemudian dilakukan untuk membuktikan bahwa supernatan yang dihasilkan dari proses sebelumnya adalah ekstrak kasar enzim kitinase, serta untuk mengetahui unit aktivitas enzim kitinase yang dihasilkan. Uji aktivitas kitinase dilakukan dengan menambahkan $1600 \mu \mathrm{L}$ substrat koloidal kitin 1\% dengan $400 \mu \mathrm{L}$ ekstrak enzim kasar kitinase, kemudian diukur absorbansinya menggunakan Spektrofotometer UV-Vis pada panjang gelombang $660 \mathrm{~nm}$ (Kholifah, 2013). Unit aktivitas enzim didefinisikan sebagai jumlah enzim yang menghidrolisis kitin per $\mathrm{mg}$ per $\mathrm{mL}$ per menit pada kondisi percobaan.

\section{Optimasi waktu fermentasi}

Untuk mendapatkan jumlah enzim yang maksimal, perlu diketahui aktivitas Aspergillus niger dalam menghasilkan enzim kitinase. Dalam penelitian ini dilakukan uji aktivitas yang disampling tiap 4 jam sekali untuk mendapatkan waktu fermentasi optimal sehingga dapat diketahui kapan enzim dapat dipanen. Grafik hubungan antara waktu fermentasi dengan absorbansi ditunjukkan pada Gambar 2.

Dari Gambar 2 menunjukkan bahwa produktivitas kitinase terus mengalami peningkatan seiring bertambahnya waktu fermentasi hingga mencapai titik optimum yaitu 52 jam. Dalam produksi enzim ini kapang berasa pada fase stasioner, yakni kurang lebih 1,5 hari setelah fase pertumbuhan. Singkatnya kapang dalam produksi enzim kitinase ini karena tidak diperlukan lagi waktu adaptasi yang cukup lama akibat nutrien yang tersedia dan kondisi lingkungan yang baru tidak berbeda dengan sebelumnya, sehingga tidak diperlukan waktu penyesuaian yang lama untuk mensintesis enzim-enzim. Setelah mencapai titik optimum secara perlahan aktivitas enzim kitinase semakin menurun. Hal tersebut karena sel telah banyak yang mati sehingga berdampak pada menurunnya enzim yang dihasilkan.

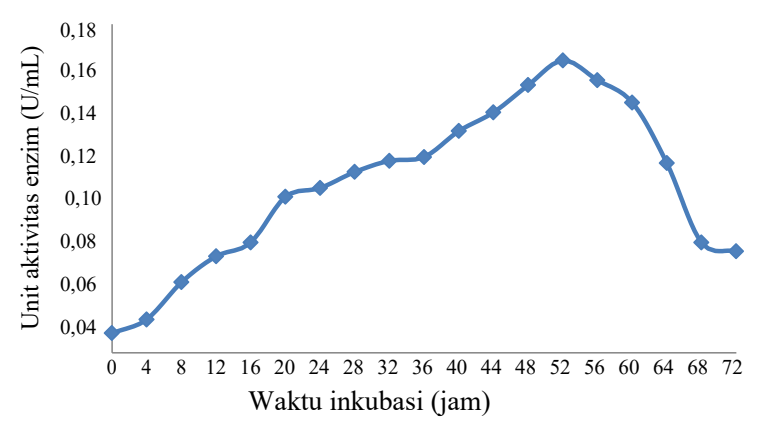

Gambar 2. Profil produktivitas enzim kitinase dari Aspergillus niger

\section{Optimasi konsentrasi molase}

Berdasarkan hasil dari Balai Penelitian Tanaman dan Sayuran (2010) molase memiliki kandungan $\mathrm{MgO}, \mathrm{Fe}, \mathrm{Mn}$, dan $\mathrm{Zn}$ masing-masing 0,37 \%, 226 ppm, 31 ppm, dan 10 ppm serta kadar gula total sebesar 43,98 \% (Widyanti, 2010). Kandungan ion logam dan gula ini diperlukan dalam proses fermentasi untuk memberikan nutrien kepada kapang agar bisa hidup, namun jika ditambahkan dalam keadaan berlebih juga akan mengganggu produktivitas enzim sehingga dalam penelitian ini dilakukan optimasi jumlah molase yang akan ditambahkan. Grafik hubungan antara konsentrasi molase dan unit aktivitas enzim ditampilkan Gambar 3.

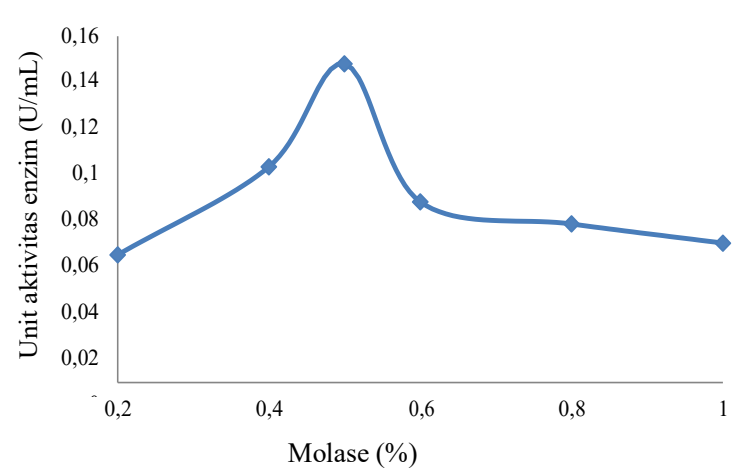

Gambar 3. Profil penentuan konsentrasi molase optimum. 
Dari Gambar 3 dapat dilihat bahwa enzim kitinase yang dihasilkan meningkat seiring dengan meningkatnya konsentrasi molase yang ditambahkan sampai pada konsentrasi $0,5 \%$ dengan aktivitas enzim $0,14726(\mathrm{U} / \mathrm{mL})$ namun setelah itu mengalami penurunan. Hal ini dikarenakan apabila jumlah molase yang ditambahkan terlampau besar Aspergillus niger akan lebih menggunakan molase Untuk proses metabolismenya dibandingkan dengan menggunakan cangkang rajungan untuk menghasilkan metabolit sekunder enzim kitinase.

\section{Optimasi konsentrasi cangkang rajungan}

Enzim kitinase dari Aspergillus niger merupakan golongan enzim induktif, dimana proses biosintesinya memerlukan induser. Jika kitin yang berfungsi sebagai induser tersebut tersedia, maka induser akan mengikat protein repressor sehingga protein repressor mengalami perubahan alosterik yang dapat mengubah bentuk dan menyebabkan represor tidak lagi mampu mengikat ke operator. Akibatnya RNA polimerase dapat mentranskripsi gen yang dibutuhkan untuk degradasi kitin dan bakteri mampu mensintesis enzim yang diperlukan untuk metabolismenya. Dalam hal ini digunakan cangkang rajungan sebagai sumber kitin karena melimpahnya kandungan yang dimiliki. Grafik hubungan antara konsentrasi cangkang rajungan dan unit aktivitas enzim ditampilkan Gambar 4.

Dari Gambar 4 diperoleh bahwa peningkatan konsentrasi induser berabanding lurus dengan tingginya produksi enzim kitinase. Tahap ini hanya berlangsung hingga tercapainya konsentrasi optimum induser sebesar 2,0\% dengan aktivitas enzim 0,12826 (U/mL), selebihnya produktivitas enzim mengalami penurunan. Konsentrasi induser yang kecil menyebabkan afinitas pengikat repressor oleh induser rendah. Begitu pula sebaliknya, konsentrasi induser yang terlalu besar menyebabkan kejenuhan pada produktivitas enzim kitinase. Karena konsentrasi induser yang terlampau besar dapat menghambat terbentuknya kompleks enzim substrat sehingga produksi enzim tidak berjalan maksimal.

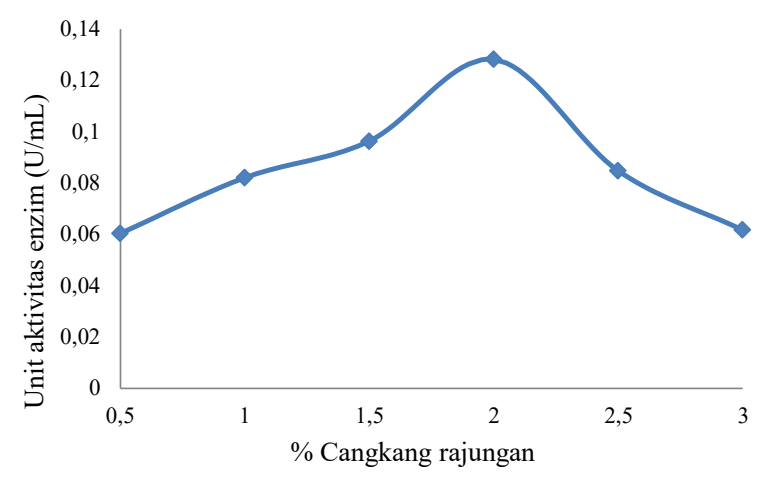

Gambar 4. Profil penentuan konsentrasi cangkang rajungan

\section{Penentuan pH optimum enzim kitinase}

Salah satu faktor yang mempengaruhi aktivitas enzim adalah $\mathrm{pH}$, karena pengikatan enzim dengan substrat dan reaksi katalisisnya bergantung pada interaksi antara substrat dengan rantai samping asam amnino penyusun sisi aktif enzim (Bender, 2002). Untuk mengetahui $\mathrm{pH}$ optimum enzim kitinase, dilakukan penambahan bufer dengan $\mathrm{pH} 3 ; 4 ; 5 ; 6 ; 7$; dan 8 menggunakan suhu $37{ }^{\circ} \mathrm{C}$. Kurva hubungan antara $\mathrm{pH}$ dengan aktivitas enzim ditampilkan pada Gambar 5.

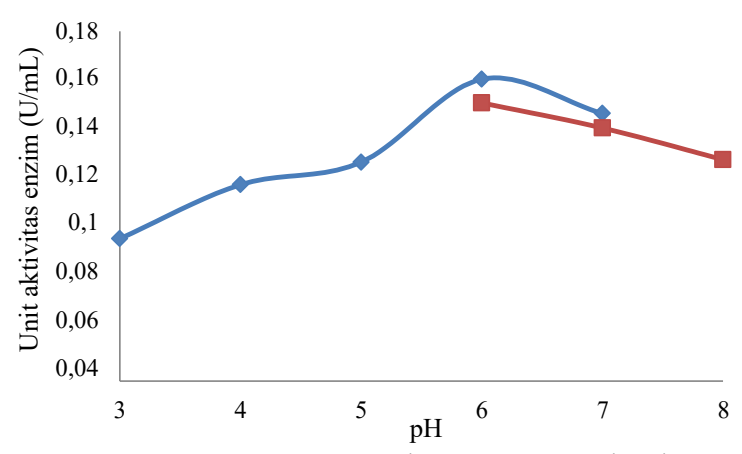

Gambar 5. Pengaruh $\mathrm{pH}$ terhadap aktivitas enzim

Berdasarkan Gambar 5 diperoleh $\mathrm{pH}$ optimum enzim kitinase adalah 6 karena menunjukkan absorbansi yang terbesar dibanding yang lain dengan aktivitas enzim $0,1554(\mathrm{U} / \mathrm{mL})$. Dalam penelitian 
ini dilakukan uji pada $\mathrm{pH}$ 3-7 menggunakan bufer sitrat fosfat dan $\mathrm{pH} 6$ 8 menggunakan bufer fosfat.

\section{Penentuan suhu optimum enzim kitinase}

Aktivitas enzim dipengaruhi oleh beberapa faktor, salah satunya adalah suhu. Hal ini dikarenakan seperti halnya pada reaksi kimia lainnya, tingkat katalisis reaksi oleh enzim akan meningkat seiring dengan peningkatan suhu (Polgar, 1990). Bertambahnya suhu sampai dengan suhu optimum menyebabkan terjadinya kenaikan kecepatan reaksi enzim karena bertambahnya energi kinetik yang mempercepat gerak enzim dan substrat. Namun apabila enzim berada di atas suhu optimumnya maka aktivitas akan menurun. Hal ini terjadi karena enzim termasuk jenis protein yang dapat mengalami denaturasi pada suhu tinggi. Denaturasi ini menyebabkan perubahan pada konformasi enzim akibat adanya perenggangan ikatan hidrogen yang bersifat reversibel sehingga dapat mempengaruhi sisi aktif enzim untuk berikatan dengan substrat (Mulyani dkk., 2009).

Untuk mengetahui suhu optimum enzim kitinase dilakukan penentuan suhu optimum pada rentang antara $20-60{ }^{\circ} \mathrm{C}$ dan menggunakan buffer $\mathrm{pH} 6$, yakni $\mathrm{pH}$ optimum yang telah didapatkan sebelumnya. Grafik nilai absorbansi hubungan antara suhu dengan aktivitas enzim ditampilkan Gambar 6.

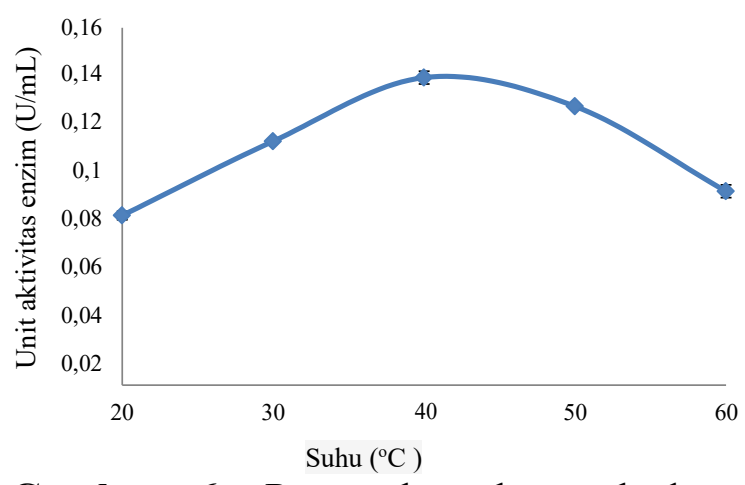

Gambar 6. Pengaruh suhu terhadap aktivitas enzim
Dalam penelitian ini diperoleh suhu optimum enzim kitinase $40{ }^{\circ} \mathrm{C}$ karena menunjukkan absorbansi yang terbesar dibanding menggunakan suhu inkubasi yang lain, dengan aktivitas enzim 0, 1377 (U/mL). Suhu optimum enzim kitinase dari Aspergillus niger ini tergolong cukup tinggi. Hal ini dikarenakan Aspergillus niger bersifat mesofilik (Fardiaz, 1989) sehingga enzim yang dihasilkan juga bersifat tahan terhadap panas.

\section{Kesimpulan}

Dari penelitian ini didapatkan bahwa jumlah optimum substrat molase yang ditambahkan dalam produksi enzim kitinase dari Aspergillus niger adalah 0,5\% (b/v) dengan aktivitas enzim yang dihasilkan 0,13776 (U/mL). Sedangkan jumlah optimum substrat cangkang rajungan yang ditambahkan dalam produksi enzim kitinase dari Aspergillus niger adalah 2,0\% (b/v) dengan unit aktivitas enzim yang dihasilkan 0,07682 (U/mL). Enzim kitinase dari Aspergillus niger yang dihasilkan mempunyai $\mathrm{pH}$ optimum 6 dan suhu optimum $40{ }^{\circ} \mathrm{C}$.

\section{Ucapan Terima Kasih}

Terima kasih disampaikan kepada Direktorat Jenderal Pendidikan Tinggi yang membiayai penelitian ini, melalui Kontrak Nomor: 004/SP2H/KPM/DIT. LITABMAS/V/2013

\section{Daftar Pustaka}

Chen, J. K., Shen, C. R. and Liu, C. L. (2010). N-acetylglucosamine: Production and Applications, Journal of Marine Drugs, 8, 2493 - 2516

Fardiaz, S. (1989). Fisiologi Fermentasi, Pusat Antar Universitas ITB, Bandung

Kholifah, A. (2013). Pemurnian Parsial dan Uji Stabilitas Enzim Kitinase dan $\beta$-1,3-Glukanase dari Cairan Digestif Achatina fulica, Skripsi, Jurusan Kimia Fakultas Sains dan Teknologi Universitas Airlangga, Surabaya 
Maggadani, B. P. (2012). Optimasi Produksi N-asetilglukosamin dari Kitin Menggunakan Kitinase Hasil Isolasi Bakteri, Tesis, Pasca Sarjana Universitas Indonesia, Depok

Mulyani, N. S., Asy'ari, M. dan Prasetiyoningsih, H. (2009). Penentuan Konsentrasi Optimum Oat Spelt Xylan Pada Produksi Xilanase dari Aspergillus niger Dalam Media PDB (Potato Dextrose Broth), Journal Kimia Sains \& Aplikasi, XII, $1-10$

Patil, R. S., Ghormade, V. and Deshpande, M. V. (2000). Chitinolytic Enzymes Exploration, Enzyme and Microbial Technology, 26, $473-483$

Sashiwa, H., Fujishima, S., Yamano, N. Kawasaki, N., Nakayama, A., Muraki, E., Hiraga, K., Oda, K. and Aiba, S. (2002). Production of NAcetyl-D-glucosamine from $\alpha$-Chitin by Crude Enzymes from Aeromonas hydrophila H2330, Carbohydrate Research, 337, 761 - 763.

Toharisman, A. (2007). Peluang Pemanfaatan Enzim Kitinase Di Industri Gula, Laporan Hasil Penelitian, P3GI Pasuruan.

Widyanti, E. M. (2010). Produksi Asam Sitrat Dari Substrat Molase pada Pengaruh Penambahan VCO (Virgin Coconut Oil) Terhadap Produktivitas Aspergillus Niger Itbcc L74 Terimobilisasi, Tesis, Universitas Diponegoro, Semarang 